\title{
Upaya pengembangan objek wisata air terjun (majaujau) desa sagulubbeg kecamatan siberut barat daya
}

\author{
Sarbaitinil ${ }^{1}$, Waza Karia Akbar ${ }^{2}$, Riki $^{3}$, \\ ${ }^{1}$ Program Studi Pendidikan Sosiologi, STKIP PGRI Sumatera Barat, ${ }^{2}$ Program Studi Pendidikan Ilmu \\ Pengetahuan Sosial, STKIP PGRI Sumatera Barat, ${ }^{3}$ Program Studi Pendidikan Sosiologi, STKIP \\ PGRI Sumatera Barat, Jalan Gunung Pangilun, Padang \\ E-Mail:stkip_pgripadang@yahoo.co.id \\ Email : $\underline{\text { bet_sarbaitinil@yahoo.co.id, }}$ 르azasolok@gmail.com, ${ }^{3}$ rikisgps@ gmail.com
}

\begin{abstract}
Abstrak
Obyek wisa ta adalah segala sesuatu yang unik, indah, dan bernilai tinggi berupa keanekaragaman kekayaan alam dan buatan yang menjadi sasaran a tau tujuan kunjungan wisatawan dan daerah tujuan wisata disebut destinasi pariwisa ta sebagai tujuan wisata, Dusun Kaleak, Sagulubbeg. Desa Siberut Barat Daya Kabupaten Siberut memiliki objek wisa ta berupa air terjun Majaujau yang berpotensi untuk dikembangkan menjadi destinasi wisata di Pulau Mentawai. Namun dalam perkembangannya objek wisata ini belum tertata dengan baik, oleh ka rena itu perlu adanya upaya pemerintah dan masyarakat untuk mengembangkan destinasi wisa ta ini. Teori yang digunakan dalam penelitian ini a dalah teori fungsional struktural Robert K. Merton. Penelitian ini merupakan penelitian deskriptif kualitatif. Pengambilan informan dengan cara purposive sampling dengan informan. Metode pengumpulan data yang digunakan a dalah observasi, wa wancara, dan studi dokumen. Analisis da ta dilakukan dengan pengumpulan data, penyajian data dan penarikan kesimpulan. Hasil penelitian ini menunjukkan bahwa pemerintah telah melakukan upaya pengembangan objek wisa ta air terjun Majaujau, walaupun belum maksimal na mun perkembangan tersebut dapat dilihat melalui da ya tarik, aksesibilitas, fasilitas, dan kelembagaan yang semuanya a da di dala mnya. Bentuk: pembangunan WC umum, promosi berupa spanduk, pertunjukan Tunuk Langgai di daerah. Daya tarik wisata, sedangkan masyarakat berupaya berpromosi melalui penerapan sapta pesona. Pengelola a ir terjun Majaujau a dalah kepala desa dan masyarakat sekitar.
\end{abstract}

Kata Kunci: Pengembangan, Da ya Tarik Wisata, Pemerintah

\begin{abstract}
A tourist objct is a nything that is unique, beatiful, and valuable in the form of a diversity of natural and man-made wealth thatis the target or destination of tourist visits and tourist destinations are called tourism destinations a s a tourism destination, Ka leak hamlet, Sa gulubbeg village, southwest Siberut district, has a tourist attraction in the form of a Majaujau waterfall which has the potential to be developed into a tourism destination in the Mentawai Island. However, in its development, this tourist attraction has not beben well orgnized, there fore goverment and community efforts are needed to develop this touristdestintion. Theory used in this research is structural functional theory by Robert K. Merton. Thhis research is a qualitative descritive research. Retneval of informant means of purposive sampling with is informants. Data collection methods used were observation, interviews, and document study. Data a nalysis was carried out by colecting data, presenting da ta and drawing conclusions. The results of this study indicate that the goverment hs madeefforts to develop the tourism object of the Majaujau waterfall, lthough it has not been maximized, this development can be seen through the reans of attrctions, accessebility, faculities, and institutions which are all in the form of: concruction of public toilets, promotion inthe form of banners, Turuk Langgai performnces in the regions. Tourist attraction, while the community seeks to promote through applying spta pesona. The manager of the Majaujau waterfall is the village hed and the localcommunity.
\end{abstract}

Keywords: Development, Tourist Attraction, Goverment. 


\section{PENDAHULUAN}

Pariwisata merupakan aktivitas pelayanan dan produk hasil industri pariwisata yang mampu menciptakan pengalaman perjalan bagi wisatawan, unsur pembentuk pengalaman wisatawan yang utama adalah adanya daya tarik dari suatu tempat atau lokasi (Gartner, 1996). Kata pariwisata berasal dari dua suku yaitu "pari" dan "wisata". Pari berarti banyak, berkli-kali dn berputar-putar, sedangkan wista berarti perjalanan atau bepergian yang dilkukan secara berkali-kali atau berkeliling. Pariwisata adalah paduan Bahasa Indonesia untuk istilah tourism dalam Bahasa Inggris (A.J. Muljadi, 2012).

Menurut Undang-Undang RI No Tahun 2009 pasal 3 tentang fungsi kepriwistaan, pariwisata berfungsi memenuhi kebutuhan jasmani, rohani dan intelektual setiap wisatawan dengan rekreasi dan perjalanan serta meningkatkan pendapatan negara untuk mewujudkan kesehjteraan rakyat. Dipandang dari segi sifatnya objek wisata dibagi beberapa bentuk yaitu (1) objek wisata alam yaitu objek wisata yang benar-benar belum dibentuk oleh kreativitas tangan manusia misalnya seperti air terjun, sungai dan sebagainya (2) objek wisata budaya, adalah objek wisata yang mendukung unsur-unsur budaya seperti peninggalan sejarah (3) alam budaya yaitu objek wisata alam yang telah dimodifikasi oleh kreativitas tangan manusia agar dapat lebih menarik, seperti taman wisata Safari ((Bakaruddin, 2009).

Dusun Kaleak Desa Sagulubbeg merupakan salah satu Dusun terdapat di Kabupaten Kepulauan Mentawai. Dusun ini memiliki potensi dengan berbagai objek wisata seperti objek wisata alam yang menarik dan bisa untuk dikembangkan sebagai objek wisata budaya Sikerei dan wisata alam seperti air terjun Majaujau. Budaya Sikerei ini diperkenalkan melalui sanggar ketika diadakan fetival budaya Mentawai dan sekaligus mempromosikan budaya Sikerei.

Dalam pembangunaan kepariwisataan suatu objek wisata sudah harus dapat dipastikan apakah objek wisata tersebut telah layak atau belum untuk dikembangkan. Pembangunan kepariwisataan akan ditingkatkan dengan tujuan mengembangkan dan mendayagunakan sumber dan potensi kepariwisataan agar menjadi kegiatan ekonomi yang dapat diandalkan.

Suatu objek wisata dikatakan layak dikembangkan apabila memiliki syarat-syarat antara lain: (1) Attraction, adalah segala sesuatu yang menjadi ciri khas dan menjadi daya tarik wisatawan agar mau datang berkunjung ketempat wisata tersebut. Atraksi wisata terdiri dari 2 yaitu (a) Site Attraction, yaitu daya tarik yang dimiliki oleh objek wisata semenjak objek itu ada (b) Event Attraction, yaitu daya tarik yang dimiliki oleh suatu objek wisata setelah dibuat manusia. (2) Accessibility, yaitu kemudahan cara untuk mencapai tempat tersebut. (3) Amenity, yaitu fasilitas yang tersedia di daerah objek wisata seperti akomodasi dan restoran. (4) Instuition, yaitu lembaga atau organisasi yang mengelolah objek wisata tersebut ((Mirad, 2009).

Bila dilihat dari perkembangannya Objek wisata air terjun (Majaujau) Dusun Kaleak Desa Sagulubbeg Kecamatan Siberut Barat Daya ini belum diminati dan dikenal oleh wisatawan. Untuk menjadikan objek wisata ini dikenal dan diminati oleh wisatawan, maka pemerintah harus berupaya untuk mengembangkan kawasan objek wisata ini dengan berbagai cara, salah satunya adalah dengan menata kembali kawasan ini dengan baik, menyediakan sarana prasarana yang dibutuhkan oleh wisatawan seperti tersedianya warung-warung kecil untuk belanja makan dan minuman, tempat beristirahat dan berteduh, tersedianya air bersih, tersedianya akomodasi lainnya yang dibutuhkan wisatawan. Selanjutnya yang tidak kalah pentingnya dalam pengembangan objek wisata air terjun ini adalah mengikutsertakan masyarakat lokal, karena keterlibatan masyarakat lokal secara langsung dalam kegiatan pengembangan pariwisata pada suatu daerah dapat menjadikan kawasan tersebut jadi terpelihara dengan segala potensi yang ada, bukan malahan merusaknya.

Kemudian kalau dirasakan cukup sulit bagi objek wisata tersebut berkembang, tetapi dengan keikutsertaan dan keterlibatan masyarakat lokal untuk terlibat langsung dalam kegiatan kepariwisataan di dalam objek wisata itu sendiri. Maka, masyarakat lokal sekitarlah yang nantinya akan ikut merasakan langsung hasil yang diperoleh dari keberhasilan pengembangan obyek wisata air terjun (Majaujau) yang berada di Dusun Kaleak. Hal ini berdampak terhadap perekonomian berupa, membuka lapangan 
pekerjaan yang baru bagi sebagian besar masyarakat Dusun Kaleak yang belum memiliki mata pencaharian yang tetap dan juga memberikan pendapatan tambahan bagi masyarakat Dusun Kaleak.

Berdasarkan hasil observasi dan wawancara di lapangan, sejarahnya air terjun ini dinamakan Majaujau, karena pada tahun 1976 penduduk Paipaijet berburu ke hutan dan menemukan suatu daratan tinggi yang cocok dijadikan sebagai pemukiman. Hal inilah yang menimbulkan pemikiran untuk berpindah tempat tinggal atau wilayah dari Paipaijet ke dataran tinggi tersebut, kemudian dinamakan Kaleak. Sampai sekarang dinamai oleh pemerintah yaitu Dusun Kaleak. Setelah mereka tempati wilayah Kaleak ini, tidak lama kemudian sebagian warga Kaleak menemukan air terjun setinggi 10 meter dari jatuhnya air. Air terjun ini dinamakan Majaujau, karena dari atas air ini jatuhnya masih banyak, tapi setelah sampai ke bawah menjadi sedikit dan terpencar kemana-mana, dan itulah alasan nama air terjun menjadi Majaujau.

Air terjun Majaujau terletak di Dusun Kaleak, dapat ditempuh dengan menggunakan kendaraan pribadi roda dua dalam waktu kurang lebih setengah jam. Untuk menuju air terjun ini melewati medan jalan yang kurang bagus, karena akses jalannya yang belum permanen, ketika hari hujan masih berlumpur. Air terjun Majaujau jatuh dari ketinggian 10 meter dari puncak gunung, airnya sang at jernih, lagipula panorama alam di sekitar kawasan itu terdiri dari pegunungan dan banyak ditumbuhi pepohonan yang membuat hawa daerah itu semakin sejuk dan dingin.

Untuk mencapai kawasan air terjun, pengunjung memasuki gerbang obyek wisata air terjun Majaujau dengan melewati bebatuan yang licin, sehingga pengunjung harus berhati-hati melewati bebatuan tersebut. Prasarana bangunan seperti penginapan, tempat peristirahatan bagi pengunjung belum tersedia, dan tidak adanya tempat makan bagi pengunjung dalam menikmati keindahan air terjun Majaujau. Dari aspek keamanan dan kenyamanan bagi pengunjung juga belum terjamin, karena masih terjadinya kasus pencurian dan pemalakan terhadap wisatawan yang berkujung. Melihat kondisi ini membuat pengunjung kurang berminat untuk berwisata ke air terjun Majaujau, karena pengunjung yang pernah merasa dirugikan akan memberikan informasi verbal kepada masyarakat pengunjung lainnya. Sehingga, wisatawan yang ingin berkunjung ke objek wisata ini mengurungkan niatnya dan bahkan membatalkan kunjungannya.

Menyikapi beberapa permasalahan yang telah dikemukakan di atas diperlukan adanya upaya pemerintah dalam mengikutsertakan masyarakat lokal dusun Kaleak dalam mengembangkan obyek wisata ini agar masyarakat lokal dapat menjaga keamanan dan kenyamanan wisatawan yang berkunjung yang merupakan suatu keharusan dan disegerakan. Mengingat obyek wisata air terjun Majaujau dengan segala keindahannya adalah salah satu tempat wisata yang mempunyai potensi sangat bagus, tapi belum tertata dengan baik. Disamping itu dengan pengembangan kawasan objek wisata ini dengan baik akan berdampak terhadap peningkatan pendapatan masyarakat di daerah tersebut.

Pada dasarnya dalam pengembangan suatu objek wisata sangat dibutuhkan sinergisitas antara pemerintah, masyarakat, dan pihak swasta. Demikian juga halnya dalam pengembangan objek wisata Air terjun di Dusun Kaleak diperlukan adanya upaya dari pemerintah bersama dengan masyarakat dan pihak swasta untuk mengembangkan potensi yang dimiliki, agar diminati oleh wisatawan domestik, maupun mancanegara. Untuk saat ini kondisi air terjun di dusun Kaleak belum tertata dengan baik, fasilitas-fasilitas yang sudah ada sekarang dirasa belum memadai dalam mendukung keberadaan potensi agar menarik minat wisatawan untuk berkunjung, sehingga meningkatkan angka kunjungan wisata dan perkembangan obyek wisata ini. Padahal objek wisata ini memiliki potensi yang sangat menarik untuk dikembangkan dengan pemandangan air terjun yang indah dan dapat dimanfaatkan pengunjung untuk berenang. Oleh karena itu penelitian ini bertujuan untuk mendeskripsikan upaya pengembangan objek wisata air terjun (Majaujau) oleh pemerintah di dusun Kaleak Desa Sagulubbeg Kecamatan Siberut Barat Daya. 
Permasalahan-permasalahan di atas diperkuat oleh hasil penelitian yang dilakukan oleh Ola Olvianita (2017) Potensi Pengembangan Pariwisata Pulau Pasumpahan di Kecamatan Bungus Teluk Kabung Kota Padang. Hasil penelitiannya ini menunjukkan bahwa daya tarik yang dimiliki pulau Pasumpahan, yaitu keindahan laut dan pemandangan, dan daya tarik, dan event/atraksi wisata, seperti mengadakan orgen tunggal. Adapun potensi pembangunan dan pengembangan pulau Pasumpahan yaitu dengan kelebihan, seperti keindahan alam, lautnya, kemudian memiliki puncak bukit yang tingginya $100 \mathrm{~m}$, kesejukan, sikap ramah tamah dan juga dihiasi dengan tulisan pulau pasumpahan untuk pengunjung yang berfoto-foto, adapun kekurangan yangterdapat di pulau Pasumpahan seperti, infrastruktur jalan belum lancar dari simpang Teluk Kabung menuju Sungai Pisang, wahana permainanbelum lengkap, dan masih kekurangan air bersih. Adapun peluang yang harus di kembangkan yaitu area permainan yang kurang lengkap, kesediaanya air bersih yang dengan cukup, dan ancaman yaitu, perilaku penyimpang dan konflik perebutan pengunjung.

\section{METODE PENELITIAN}

Penelitian ini menggunakan penelitian kualitatif dengan tipe deskriptif. Pendekatan ini meruuupakan suatu pendekatan yang bermaksud untuk memahami tentang apa yang dialami oleh subjek perhatian, data yang diperoleh dapat berbentuk kata-kata, gambaran holistik dan rumit ((Moleong, 2007)Pemilihan metode penelitian ini dianggap mampu menggambarkan suatu kenyataan atau fenomena yang ada dan menjelaskan masalah yang diteliti secara mendalam tentang upaya pengembangan objek wisata air terjun Majaujau di Dusun Kaleak Desa Sagulubbeg Kecamatan Siberut Barat Daya. Tipe penelitian deskriptif yaitu penelitin yang dimaksudkan untuk mengetahui situasi secara mendalam dengan fenomena yang diteliti ((Afrizal, 2014)).

Pendekatan Penelitian kualitatif dengan tipe deskriptif digunakan untuk mengetahui, mengungkapkan, mendeskripsikan dan untuk mengetahui situasi secara mendalam mengenai upaya pengembangan objek wisata air terjun Majaujau di Dusun Kaleak Desa Sagulubbeg Kecamatan Siberut Barat Daya. Dalam penelitian ini penulis menggunakan teknik purposive sampling, karena mengetahui tentang upaya pengembangan objek wisata air terjun Majaujau di Dusun kaleak Desa Sagulubbeg. Hal ini informan juga memiliki kriteria-kriteria dalam mendapatkan informasi yang valid dengan jumlah informn sebanyak 15 orang yang terkait mengenai upaya pengembangan objek wisata air terjun Majaujau Di Dusun Kaleak Desa Sagulubbeg Kecamatan Siberut Bart Daya tersebut.

Menurut (Sugiyono, 2012) dapat dibedakan dalam dua bentuk yaitu participant obsevation dan non-participant observation. Dalam penelitian ini peneliti menggunakan non-participant observation yaitu suatu bentuk observasi yang dilakukan dengan melihat dan menggambarkan semua aktivitasaktivitas di lapangan yang terjadi. Maksudnya dimana peneliti tidak ikut didalam kehidupan orang yang akan diobservasi, dan secara terpisah berkedudukan selaku pengamat. Dalam penelitian ini melakukan observasi di Dusun Kaleak Desa Sagulubbeg pada tanggal 10 Februari 2020. Observasi pada tempat diketahui oleh subjek yang diteliti. Adapun yang diobservasi melihat kondisi objek wisata air terjun Majaujau, kondisi jalannya untuk menuju ke air terjun dan fasilitas seperti sarana dan prasarana yang terdapat di objek air terjun Majaujau.

Upaya pengembangan objek wisata air terjun Majaujau di Dusun kalek Desa Sagulubbeg kecamtn Siberut Barat Daya. Dimana peneliti melakukan beberapa tahap dalam untuk obervasi. Pertama peneliti melakukan pemantauan jalan menuju objek wisata air terjun dengan memakai kendaraan roda dua dan terakhir peneliti melihat fasilitas seperti sarana dan prasarana di objek wisata tersebut. Wawancara mendalam bersifat terbuka dalam pelaksanaannya tidak hanya mewancarai satu kali saja tetapi berulang-ulang dalam kenyataan melalui pengamatan (Afrizal, 2014).

Penelitian ini dilakukan dengan cara mengunjungi yang terkait yaitu pengelola, kepala Desa Sagulubbeg, masyarakat setempat dan pengunjung objek wisata air terjun Majaujau secara tatap muka. Sebelum melakukan wawancara terhadap informan yang ditentukan, terlebih dahulu peneliti membuat 
pedoman wawancara yang berisikan pertanyaan-pertanyaan yang berkenaan dengan upaya pengembangan objek wisata air terjun Majaujau di Dusun Kaleak. Wawancara dilakukan bersifat tidak terstruktur karena peneliti mengacak pertanyaan yang sudah disiapkan.

\section{HASIL DAN PEMBAHASAN}

Pengembangan objek wisata di Dusun Kaleak Desa Sagulubbeg Kecamatan Siberut Barat Daya dikelola kurang baik, peningkatan objek wisata mengalami mulai dari 2015-2019 wisatawan terus merosot dari tahun ke tahun, sarana prasarana yng kurang mendukung mengakibatkan penurunan wisatawan baik yang datang dari dalam maupun yang datang dari luar daerah. Berikut dapat dilihat data kunjungan wisatawan Air Terjun (Majaujau) dari tahun 2015 hingga 2019:

Tabel 1 Data Kunjungan Wisatawan Air Terjun (Majaujau) di Dusun Kaleak

\begin{tabular}{cccc}
\hline Tahun & Wisatawan luar & $\begin{array}{l}\text { Pengunjung } \\
\text { Wisatawan lokal }\end{array}$ & Jumlah \\
\hline 2015 & 476 & 358 & 834 \\
2016 & 410 & 246 & 656 \\
2017 & 313 & 228 & 541 \\
2018 & 251 & 137 & 388 \\
2019 & 162 & 112 & 274 \\
\hline
\end{tabular}

Sumber: Buku data kunjungan wisatawan (2019)

Berdasarkan tabel di atas diketahui bahwa pengunjung objek wisata air terjun (Majaujau) di Dusun Kaleak Desa Sagulubbeg Kecamatan Siberut Barat Daya dari tahun 2015 mengalami penurunan secara signifikan, di tahun 2015 pengunjung mencapai 834 pengunjung. Ditahun selanjutnya jumlah pengunjung sudah mengalami penurunan, pada tahun 2018 objek wisata air terjun (Majaujau) dikunjungi oleh 388 wisatawan lokal maupun luar daerah. Sedangkan pada tahun 2019 objek wisata air terjun (Majaujau) berpotensi mengalami penurunan, dikarenakan jumlah pengunjung dari bulan Januari sampai bulan Mei mencapai 274 pengunjung wisata air terjun (Majaujau).

Menyikapi kondisi di atas, maka pemerintah sudah berupaya untuk mengembangkan objek wisata air terjun Majaujau meskipun belum sesuai dengan harapan wisatawan yang berkunjung. Adapun syarat untuk mengembangkan suatu objek wisata menurut Riko Mirad Sinarta (2009), yaitu: atraksi, aksesibilitas, amenitas, dan institusi. Untuk itu upaya pemerintah dalam mengembangkan objek wisata air terjun Maujaujau ini dapat dianalisis melalui beberapa bidang sebagai berikut:

\section{Bidang Atraksi}

Atraksi merupakan komponen yang signifikan dalam menarik wisatawan. Suatu daerah dapat menjadi tujuan wisata jika kondisinya mendukung untuk dikembangkan menjadi sebuah atraksi wisata. Apa yang dikembangkan menjadi atraksi wisata itulah yang disebut modal atau sumber kepariwisataan. Untuk menemukan potensi kepariwisataan di suatu daerah orang harus berpedoman kepada apa yang dicari oleh wisatawan yaitu, atraksi wisata budaya dan atraksi buatan manusia itu sendiri. Modal kepariwisataan itu dapat dikembangkan menjadi atraksi wisata di tempat dimana modal tersebut ditemukan. Ada modal kepariwisataan yang dapat dikembangkan, sehingga dapat menahan wisatawan selama berhari-hari dan dapat berkli-kali dinikmati, atau bahkan pada kesempatan lain wisatawan bisa berkunjung ke tempat yang sama. Keberadaan atraksi menjadi alasan serta motivasi wisatawan untuk mengunjungi suatu daya tarik wisata (DTW). Berdasarkan hasil penelitian dapat diketahui bahwa atraksi bagi pengunjung bisa dinikmati berupa pemandangan yang ada diobjek wisata tersebut. Untuk itu dapat dilihat pada foto berikut: 


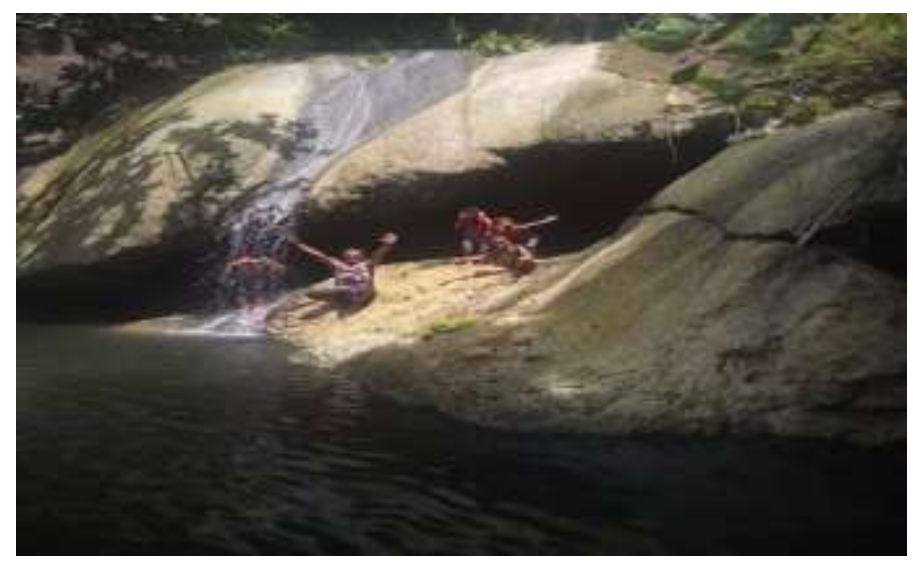

Gambar 1. Pemandangan Air Terjun Majaujau

Sumber : Dokumentasi Pribadi (2020)

Disamping itu pemerintah juga sedang mengupayakan untuk menambah wahana permainan dan hiburan serta tempat untuk menampilkan tarian tradisional Turuk Langgai. Kemudian pemerintah juga sedang mengupayakan untuk menambah sebagai menarik minat wisatawan untuk berkunjung diobjek wisata air terjun tersebut.

\section{Bidang Aksebilitas}

Aksesibilitas (Accebility) merupakan hal yang paling penting dalam kegiatan pariwisata, segala macam transportasi ataupun jasa transportasi menjadi akses penting dalam pariwisata. Di sisi lain akses ini diidentikkan dengan transferabilitas, yaitu kemudahan untuk bergerak dari daerah yang satu ke daerah lain. Jika suatu daerah tidak tersedia aksebilitas yang baik seperti bandara, pelabuhan dan jalan raya, maka tidak akan ada wisatawan yang mempengaruhi perkembangan aksebilitas di daerah tersebut. Jika suatu daerah memiliki potensi pariwisata, maka harus disediakan aksebilitas yang memadai seperti transportasi, sehingga daerah tersebut dapat dikunjungi.

Hasil penelitian dapat diketahui bahwa untuk menuju ke objek wisata tersebut masih menggunakan kendaraan pribadi, karena pemerintah belum menyediakan transportsi. Para pengunjung pun kesusahan untuk menuju ke objek wisata ketika musim hujan. Melihat kondisi seperti ini, maka pemerintah juga sedang mengupayakan untuk segera memperbaiki jalan dan akan mengupayakan alat transportasi umum untuk para pengunjung yang berkunjung ke objek wisata tersebut. Disamping alat transfortasi yang merupakan akses wisatawan ke lokasi air terjun, kondisi jalan menuju lokasi wisata juga menjadi salah satu faktor penting bagi wisatawan yang berkunjung. Untuk lebih jelasnya kondisi jalan menuju air terjun Maujaujau dapat dilhat pada foto berikut:

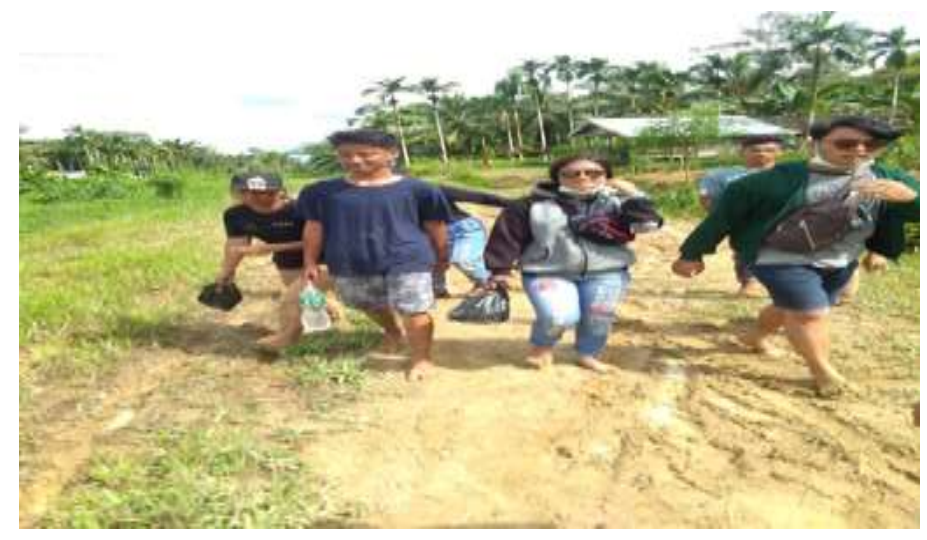

Gambar 2. Foto Jalan Menuju Air Terjun

Sumber : Dokumentasi Pribadi (2020) 


\section{Bidang Fasilitas}

Fasilitas (Amenity) merupakan segala macam sarana dan prasarana yang diperlukan oleh wisatawan selama berada di daerah tujuan wisata. Sarana dan prasarana yang dimaksud seperti: penginapan, rumah makan, transpotasi dan agen perjalanan. Dengan menggunakan prasarana yang cocok dibangunlah sarana-sarana pariwisata seperti hotel, atraksi wisata, marina, gedung pertunjukan, dan sebagainya. Adapun prasarana yang banyak diperlukan untuk pembangunan sarana-sarana pariwisata ialah jalan raya, persediaan air, tenaga listrik, tempat pembuangan sampah, bandara, pelabuhan, telepon, dan lain-lain. Mengingat hubungan antar sarana dan prasarana, sudah jelas bahwa pembangunan prasarana pada umumnya harus mendahului sarana. Ada saatnya prasarana dibangun bersama-sama dalam rangka pembangunan sarana wisata. Suatu tempat atau daerah dapat berkembang sebagai daerah tujuan wisata apabila aksebilitasnya baik. Ada hubungan timbal balik antara sarana dan prasarana. Prasarana merupakan syarat untuk sarana, dan sebaliknya sarana dapat menyebabkan perbaikan prasarana.

Pemerintah telah mengupayakan dan akan menambah atau sudah merencanakan untuk melengkapi fasilitas air terjun Majaujau ini seperti membangun penginapan maupun penerangan/listrik, mushola, meskipun masih tahap perencanaan pembangunan.

Penyediaan fasilitas untuk menunjang adanya daya tarik objek wisata bagi pengunjung, pemerintah sudah mengupayakan untuk membangun dan menyediakan WC umum di lokasi objek wisata air terjun ini serti foto berikut:

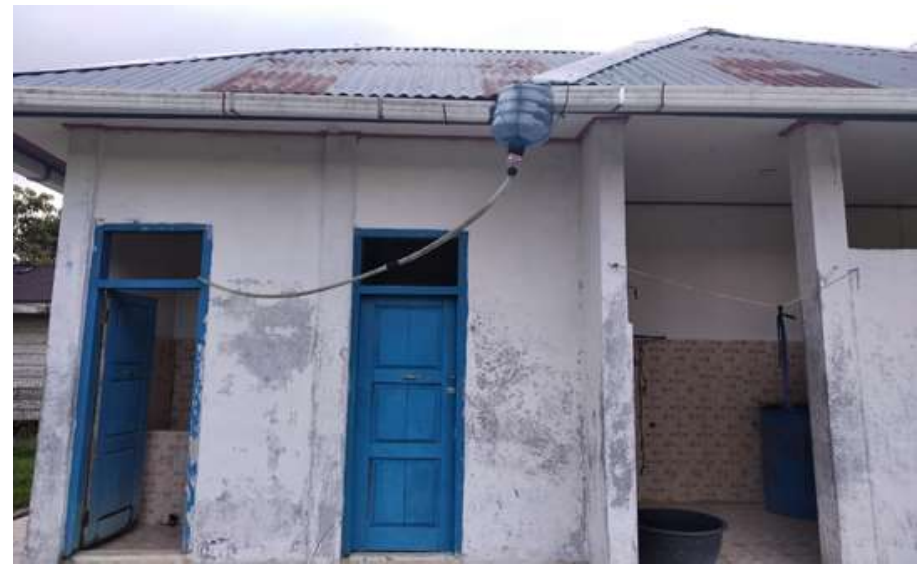

Gambar 3. Kondisi WC di Air Terjun Majaujau

Sumber : Dokumentasi Pribadi (2020)

4. Bidang Lembaga

Intitution merupakan hal-hal yang mendukung sebuah kepariwisataan, seperti lembaga pengelolaan, tourist information, travel agent dan stakeholder yang berperan dalam kepariwisataan dan suatu integrasi antara pemerintah, organisasi, pelaku pariwisata dan teknis pelaksanaan yang berlangsung secara terus-menerus, agar tujuan kepariwisataan secara nasional, regional dan lokal dapat tercapai.

Lembaga pengelolaan objek wisata masih dikelola kepala desa dan bekerja sama dengan masyarakat lokal dalam pengembangan objek wisata serta promosi air terjun Majaujau yang sudah dilakukan adalah dengan membentuk spanduk serta mengadakan acara pertunjukan budaya Turuk Langgai atau hiburan yang berlokasikan didaerah objek wisata tersebut. Kemudian untuk promosinya 
ada juga dari masyarakat yang mengupload foto di facebook dan untuk mengelola air terjun Majaujau untuk sementara masih dilakukan oleh kepala desa yang bekerja sama dengan masyarakat setempat.

\section{Menerapkan Sapta Pesona Di Objek Wisata Air Terjun Majaujau}

Sapta pesona pada objek wisata air terjun Majaujau adalah keadaan alamnya masih sejuk, pemandangan yang indah dikelilingi oleh perbukitan yang menambah indahnya pemandangan $\mathrm{dn}$ masyarakatnya ramah tamah. Namun tempat parkir dan tempat istirahat pengunjung belum tertata dengan rapi, sehingga pengunjung merasa kurang nyaman saat berkunjung ke objek wisata ini. Hal ini dikarenakan belum adanya petugas keamanan yng menjaga kemanan dan kenyamanan pengunjung selama berada di lokasi objek wisata ini dan juga belum tersedianya sarana yang dibutuhkan wisatawan yang berkunjung.

Dalam analisis karya ilmiah ini teori yang digunakan adalah teori Struktural Fungsional menurut Robert K.Merton menurut teori ini masyarakat merupakan salah satu sistem sosial yang terdiri dari bagian-bagian atau elemen-elemen yang saling berkaitan dan saling menyatu dalam keseimbangan perubahan yng terjadi satu bagian akan membawa perubahan pula terhadap bagian pula terhadap bagian yang lain. Asumsi dasarnya adalah setiap struktur dan sistem sosial, fungsional terhadap yang lainnya. Sebaliknya kalau tidak fungsional, maka struktur itu tidak akan hilang dengan sendirinya. Tingkat analisis Merton lebih kepada institusi, kelompok, masyarakat, dan kultur. Merton melihat suatu institusi atau pranata tertentu dapat fungsional bagi unit sosial tertentu dan sebaliknya dis-fungsi bagi unit sosial lainnya (Ritzer, 2011)).

Seperti yang sudah dibahas mengenai pendekatan teoritis, teori yang digunakan yaitu teori Struktural Fungsional yang dipaparkan bahwa teori ini menyangkut kedalam masalah yang diteliti mengenai upaya pengembangan objek wisata air terjun Majaujau di Dusun Kaleak Desa Sagulubbeg Kecamatan Siberut Barat Daya dapat dijelaskan oleh teori struktural fungsional dengan upaya pengembangan objek wisata air terjun Majaujau yang dilakukan oleh pemerintah dusun Kaleak Desa Sagulubbeg adalah berfokus bahwa pada sistem dan struktur yang menyebabkan terjadinya perubahan bagi masyarakat sekitar dusun kaleak. Perubahan tersebut terjadi secara perlahan yang diiringi dengan sistem sosial, yang membentuk suatu pembangunan baik dari sarana maupun prasarana yang dilakukan oleh masyarakat dusun Kaleak terhadap objek wisata air terjun Majaujau juga dapat menguntungkan masyarakat pada sektor ekonominya. Dalam hal ini pemerintah sudah mengupayakan dalam memberikan pemahaman kepada masyarakat melalui sosialisasi sapta pesona. Untuk itu dapat dilihat pada foto berikut:

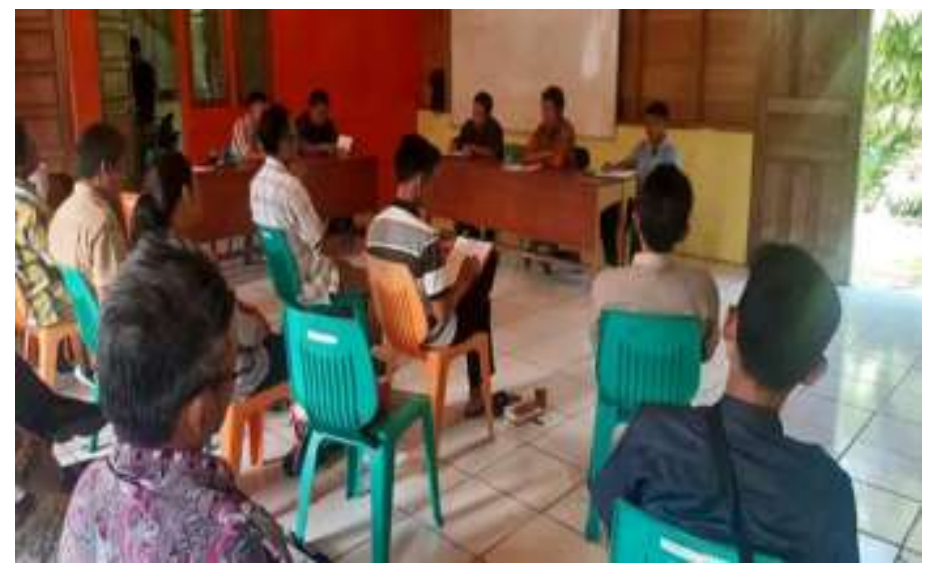

Foto 4. Sosialisasi Pembinaan Masyarakat oleh Dinas Pariwisata

Sumber : Dokumentasi Pribadi (2020) 


\section{KESIMPULAN}

Berdasarkan hasil penelitian dapat disimpulkan melalui beberapa bidang yaitu, (1) Atraksi, untuk atraksi pertunjukan budaya tarian Turuk Langgai dan diadakan setiap tahun baru. Untuk itu pemerintah juga akan segera mengupayakan menambah wahana hiburan/permainan di objek wisata air terjun Majaujau tersebut (2) Aksebilitas, untuk menuju air terjun para pengunjung masih menggunakan kenderaan pribadi dikarenakan dari pemerintah/dinas pariwisata belum menyediakan transportasi umum, tetapi pemerintah juga akan mengupayakan untuk segera menyediakan alat transportasi untuk para pengunjung objek wisata air terjun Majaujau akses berupa jalan menuju air terjun Majaujau tersebut (3) Fasilitas, untuk fasilitas yang dibutuhkan wisatawan di Dusun kaleak ini hanya terdapat WC, sedangkan yang lainnya pemerintah sudah merencanakan atau mengupayakan untuk segera membangun penginapan, rumah makan agar para pengunjung nyaman untuk berwisata (4) Institusi, untuk pengelolaan objek wisata air terjun Majaujau Dusun Kaleak ini dikelola oleh kepala Desa yang bekerja sama dengan masyarakat setempat dalam mengembangkan objek wisata ini.

Kemudian promosi berbentuk spanduk. Sedangkan masyarakat berupaya mempromosikan melalui facebook, sosialisasi pembinaan masyarakat oleh dinas pariwisata (5) upaya menerapkan sapta pesona pada objek wisata air terjun Majaujau yang dilakukan adalah membersihkan semak-semak dan sampah yang berserahkan di sekitar air terjun, sehingga lokasi air terjun bersih dan indah, udaranya masih sejuk karena objek wisata wisata ini masih dikelilingi oleh hutan yang masih alami. Dari segi keamanan objek wisata air terjun tergolong aman meskipun di lokasi objek wisata ini belum ada petugas keamanan karena selama objek wisata ini berkembang belum pernah terjadi tindakan kekerasan meskipun kemarin-kemarin ada kehilangan uang dan hp tetapi ketertibannya masih kurang, karena tempat parkir masih belum tertata rapi, masyarakatnya pun ramah tamah, saling menghormati dan bersikap sopan santun terhadap pengunjung yang datang ke objek wisata tersebut. Hanya saja dalam hal kenang-kenangan dari objek wisata ini belum ada, karena cendera mata yng menunjukan ciri khas dari daerah tersebut belum ada.

Ucapan Terima kasih

Ucapan terima kasih pertama yakni kepada masyarakat sekitar objek wisata air terjun yang sudah menjadi informan dan membantu dalam memberikan data penelitian ini. Selanjutnya kepada pemerintah daerah khususnya dusun kaleak. Serta kepada ibuk Sarbaitinil dan bapak Waza Karia Akbar yang sudah membantu terlaksananya penelitian ini dengan lancar dan baik. Selanjutnya ucapatan terima kasih juga kami sampaikan kepada Dr Putu Sucita Yanthy, SS.M.Par selaku Editor in Chief dan dan tim editorial lainnya pada jurnal Kepariwisataan dan Hospitalitas, Fakultas Pariwisata, Universitas Udayana, Bali, Indonesia

\section{DAFTAR PUSTAKA}

A.J. Muljadi. (2012). Kepariwisataan dan Perjalanan. Rajawali Pers.

Afrizal. (2014). Penelitian Kualitatif. Rajawali Pers.

Bakaruddin. (2009). Permasalahan dan Pengembangan Kepariwisataan.

George, R. (2011). Sosiologi Ilmu Pengetahuan Berpradigma Ganda. Grafindo Persada.

Mirad, S. R. (2009). Upaya Pengembangan Objek Wisata di Kabupaten Simeulue Pasca Tsunami.

Moleong. (2007). Metodologi Penelitian Kualitatif. PT.Remaja rosdakarya.

Sugiyono. (2012). Metode Penelitian Kuantitatifdan $R \& D$. Alfabet. 